\title{
Natural jasmonates of different structures suppress the growth of human neuroblastoma cell line SH-SY5Y and its mechanisms ${ }^{1}$
}

\author{
Qiang-song TONG ${ }^{2,5}$, Guo-song JIANG ${ }^{2}$, Li-duan ZHENG ${ }^{3}$, Shao-tao TANG ${ }^{2}$, Jia-bin CAI ${ }^{2}$, Yuan LIU ${ }^{2}$, Fu-qing ZENG ${ }^{2}$, Ji-hua \\ $\mathrm{DONG}^{4}$
}

${ }^{2}$ Departments of Surgery, ${ }^{3}$ Pathology and ${ }^{4}$ Central Laboratory, Huazhong University of Science and Technology, Wuhan 430022, China

\section{Key words \\ jasmonate; neuroblastoma; proliferating cell nuclear antigen; N-myc; X-linked inhibitor of apoptosis protein; survivin \\ ${ }^{1}$ Project supported by the National Natural Science Foundation of China (No 30200284 , 30600278, and 30772359) and the Program for New Century Excellent Talents in University of China (NCET-06-0641). \\ ${ }^{5}$ Correspondence to Prof Qiang-song TONG. Phn 86-27-6377-6478. \\ E-mail qs_tong@hotmail.com}

Received 2007-12-18

Accepted 2008-04-28

doi: $10.1111 / \mathrm{j} .1745-7254.2008 .00814 . \mathrm{x}$

\begin{abstract}
Aim: Recent evidence has indicated that members of natural jasmonates, a family of plant stress hormones, exhibit anticancer activity. The current study was undertaken to investigate the effects of jasmonates on the in vitro growth of human neuroblastomas, one of the most common solid tumors in children. Methods: Cellular proliferation was measured by 3-(4,5-dimethylthiazol-2-yl)-2,5diphenyltetrazolium bromide colorimetry and colony formation assay. Apoptosis was detected by Hoechst 33258 staining and flow cytometry. Western blotting was applied to assay gene expression. Results: The administration of natural jasmonates, methyl jasmonate, cis-jasmone, and jasmonic acid to cultured neuroblastoma cell line SH-SY5Y, resulted in a decrease of cell proliferation in a doseand time-dependent manner. However, the in vitro growth of cultured human embryonic kidney (HEK) cell line HEK 293 was not affected by jasmonates. The cell cycles of jasmonate-treated SH-SY5Y cells were arrested at the $\mathrm{G}_{2} / \mathrm{M}$ phase. The incubation of SH-SY5Y cells with jasmonates resulted in characteristic changes of apoptosis. The anticancer activities of natural jasmonates on SH-SY5Y cells are as follows: methyl jasmonate $>$ cis-jasmone $>$ jasmonic acid. In addition, the expressions of proliferating cell nuclear antigen and $\mathrm{N}$-myc were downregulated by methyl jasmonate. Moreover, methyl jasmonate decreased the expression of the Xlinked inhibitor of apoptosis protein and survivin, critical members of inhibitors of the apoptosis protein family, in SH-SY5Y cells. Conclusion: Jasmonates suppress the growth of human neuroblastoma cell line SH-SY5Y via inhibiting cell proliferation and inducing apoptosis, which lays the groundwork for further investigation into the anticancer activities and its mechanisms of natural jasmonates on human neuroblastomas.
\end{abstract}

\section{Introduction}

Neuroblastomas are a highly malignant tumor derived from neural crest cells and account for approximately $10 \%$ of all childhood malignancies and $50 \%$ of childhood cancer deaths ${ }^{[1]}$. During recent years, the molecular mechanisms that control neuroblastoma development and progression have been well understood, such as the amplification of $\mathrm{N}$ myc proto-oncogene, the deletion of chromosome $1 \mathrm{p}$, and the complete or partial gain of the long arm of chromosome $17^{[2]}$. However, despite treatment regimens, including radia- tion therapy and high-dose chemotherapy with stem cell rescue, little progress has been made in improving the poor prognosis of patients with late-stage neuroblastomas because resistance to chemotherapy is common ${ }^{[3]}$. Therefore, new anticancer substances and treatment regimens are of interest.

In recent years, several groups have reported that members of jasmonates, a family of plant stress hormones, and some of their synthetic derivatives, exhibit anticancer activity in vitro and in vivo ${ }^{[4]}$. A wide spectrum of malignancies, 
including the most common human cancers, such as prostate cancer, breast cancer, and lung cancer, exhibited sensitivity to the cytotoxic effects of jasmonates ${ }^{[5,6]}$. The administration of methyl jasmonate per os daily, significantly increased the survival of lymphoma-bearing C57BL mice ${ }^{[5]}$. However, it still remains largely unknown whether jasmonates exert effects on the proliferation and apoptosis of human neuroblastoma cells. In the present study, we demonstrated for the first time that the most common natural jasmonates, methyl jasmonate, cis-jasmone, and jasmonic acid suppress the growth of cultured neuroblastoma cells. The efficiency of jasmonates was found to be correlative with their chemical structures. In addition, the anticancer effects of jasmonates on human neuroblastoma cells were associated with the downregulation of proliferating cell nuclear antigen (PCNA) and N-myc, and the modulation of the expression of the X-linked inhibitor of apoptosis protein (XIAP) and survivin, critical members of the inhibitor of the apoptosis protein (IAP) family.

\section{Materials and methods}

Cell culture and jasmonate treatment Human neuroblastoma cell line SH-SY5Y and human embryonic kidney cell line (HEK) 293 were purchased from American Type Culture Collection (USA) and grown in minimal essential medium (Life Technologies, Gaithersburg, MD, USA) supplemented with $10 \%$ fetal bovine serum (FBS; Life Technologies, USA), penicillin $(100 \mathrm{U} / \mathrm{mL})$, and streptomycin $(100 \mu \mathrm{g} / \mathrm{mL})$. The cells were maintained at $37{ }^{\circ} \mathrm{C}$ in a humidified atmosphere of $5 \% \mathrm{CO}_{2}$. Confluent monolayers of cells were incubated with different concentrations of methyl jasmonate, cisjasmone, jasmonic acid, cisplatin, or DMSO (all from Sigma, St Louis, MO, USA) as indicated.

Measurement of cell proliferation Confluent monolayers of SH-SY5Y and HEK 293 were trypsinized, and $4 \times 10^{3}$ viable cells suspended in $0.1 \mathrm{~mL}$ culture medium supplemented with $10 \%$ FBS were seeded onto each well of 96-well plates. After overnight an incubation to allow cell attachment, the cells were incubated with jasmonates $(0.5,1.5$, and 2.5 $\left.\mathrm{mmol} \cdot \mathrm{L}^{-1}\right)$, cisplatin $\left(0.025,0.05\right.$, and $\left.0.1 \mathrm{mmol} \cdot \mathrm{L}^{-1}\right)$ or DMSO for 6,12 , and $24 \mathrm{~h}$. At the end of the incubation period, cell proliferation was monitored by the 3-(4,5-dimethylthiazol-2yl)-2, 5-diphenyl tetrazolium bromide (MTT; Sigma, USA) colorimetric assay ${ }^{[7]}$. Briefly, $20 \mu \mathrm{LMTT}(5 \mathrm{mg} / \mathrm{mL})$ was added to each well. After $4 \mathrm{~h}$ of incubation at $37^{\circ} \mathrm{C}$, the cell supernatants were discarded, blue precipitate was dissolved with DMSO, and the absorbance was measured at $570 \mathrm{~nm}\left(A_{570 \mathrm{~nm}}\right)$. Cellular proliferation inhibition rates were calculated as follows: $(\%)=\left(1\right.$-average $A_{570 \mathrm{~nm}}$ value of treated cells/aver- age $A_{570 \mathrm{~nm}}$ value of untreated control cells) $\times 100 \%$. The $50 \%$ inhibitory concentration $\left(\mathrm{IC}_{50}\right)$ of $24 \mathrm{~h}$ exposure, defined as the drug concentration resulting in a $50 \%$ reduction of cell proliferation compared to untreated control cells, was determined by Bliss software (Bliss, CA, USA). All experiments were performed with 6 wells for each concentration, and at least 3 independent tests were performed.

Colony formation assay The cells were seeded at a density of $500 / \mathrm{mL}$ on $35 \mathrm{~mm}$ dishes ${ }^{[8]}$. After an overnight incubation to allow cell attachment, the cells were incubated with natural jasmonates $\left(2.5 \mathrm{mmol} \cdot \mathrm{L}^{-1}\right)$, cisplatin $\left(0.025 \mathrm{mmol} \cdot \mathrm{L}^{-1}\right)$, or DMSO as indicated. After incubation for $24 \mathrm{~h}$, the medium was replaced with fresh medium containing $10 \%$ FBS. Colonies were allowed to grow for 10-14 d. The medium was discarded and each well was carefully washed twice with phosphate-buffered saline (PBS). The cells were fixed in methanol for $15 \mathrm{~min}$ and then stained with crystal violet for 20 min. Finally, positive colony formations (more than 50 cells/colony) were counted. The survival fraction for cells was expressed as the ratio of plating efficiency of treated cells to that of untreated control cells.

Cell cycle assay According to the literature ${ }^{[9]}$, cell cycles in untreated, DMSO-, natural jasmonate- $(0.5,1.5$, and 2.5 $\left.\mathrm{mmol} \cdot \mathrm{L}^{-1}\right)$, or cisplatin $\left(0.025 \mathrm{mmol} \cdot \mathrm{L}^{-1}\right)$-treated cells were examined by flow cytometry. Briefly, $2 \times 10^{5}$ cells were collected, washed twice with $0.01 \mathrm{~mol} \cdot \mathrm{L}^{-1} \mathrm{PBS}$, and fixed in $70 \%$ ethanol overnight at $4{ }^{\circ} \mathrm{C}$. The cells were then washed once with PBS, digested by $200 \mu \mathrm{L}$ RNase $(1 \mathrm{mg} / \mathrm{mL})$ at $37^{\circ} \mathrm{C}$ for $30 \mathrm{~min}$, and stained with $800 \mu \mathrm{L}$ propidium iodide (PI; $50 \mu \mathrm{g} / \mathrm{mL}$, Sigma, USA) at room temperature for $30 \mathrm{~min}$. The DNA histograms were assayed with a flow cytometer (Becton Dickinson, San Jose, CA, USA), using CELLQEST software (Becton Dickinson, USA).

Cellular morphological observation To observe the changes in cellular morphology, Hoechst 33258 (Sigma, USA) staining was performed ${ }^{[10]}$. Briefly, cells were incubated with natural jasmonates $\left(2.5 \mathrm{mmol} \cdot \mathrm{L}^{-1}\right)$, cisplatin $\left(0.025 \mathrm{mmol} \cdot \mathrm{L}^{-1}\right)$, or DMSO as indicated, and fixed with $4 \%$ formaldehyde in PBS solution at $4{ }^{\circ} \mathrm{C}$ for $10 \mathrm{~min}$. After 3 washes with PBS, the cells were stained with $10 \mathrm{mg} / \mathrm{L}$ Hoechst 33258 in PBS solution at $4{ }^{\circ} \mathrm{C}$ in the dark for $10 \mathrm{~min}$, and morphological changes, including cell shrinkage and nuclear condensation, were observed under a fluorescence microscope (Olympus AX80; Olympus, Tokyo, Japan).

Detection of apoptosis Apoptotic ratios of cells were determined by Annexin V-fluorescein isothiocyanate (FITC; BD Pharmingen, San Diego, CA, USA) and PI staining flow cytometry $^{[11]}$. Briefly, the cells treated with natural jasmonates $\left(2.5 \mathrm{mmol} \cdot \mathrm{L}^{-1}\right)$, cisplatin $\left(0.025 \mathrm{mmol} \cdot \mathrm{L}^{-1}\right)$, or DMSO were 
collected, washed twice with cold PBS, resuspended in 100 $\mu \mathrm{L}$ binding buffer $\left(10 \mathrm{mmol} \cdot \mathrm{L}^{-1} \mathrm{HEPES}, 140 \mathrm{mmol} \cdot \mathrm{L}^{-1} \mathrm{NaCl}\right.$, and $2.5 \mathrm{mmol} \cdot \mathrm{L}^{-1} \mathrm{CaCl}_{2}, \mathrm{pH} 7.4$ ) into $2 \times 10^{5}-5 \times 10^{5}$ cells $/ \mathrm{mL}$ density, and incubated with Annexin V-FITC at room temperature for $10 \mathrm{~min}$. After washing with binding buffer, the cells were resuspended in $400 \mu \mathrm{L}$ binding buffer containing $10 \mu \mathrm{L}$ PI $(20 \mu \mathrm{g} / \mathrm{mL})$, and incubated on ice for $15 \mathrm{~min}$. Apoptosis was analyzed by a flow cytometer (Becton Dickinson, USA) at a wavelength of $488 \mathrm{~nm}$. This method can be used to distinguish living cells (Annexin $\mathrm{V}^{-} / \mathrm{PI}^{-}$), early apoptotic/primary apoptotic cells (Annexin $\mathrm{V}^{+} / \mathrm{PI}^{-}$), late apoptotic/secondary necrotic cells $\left(\right.$ Annexin $\left.\mathrm{V}^{+} / \mathrm{PI}^{+}\right)$, and necrotic cells (Annexin $\left.\mathrm{V}^{-} / \mathrm{PI}^{+}\right)^{[11]}$.

Western blotting for PCNA, N-myc, XIAP, and survivin Cells treated with methyl jasmonate $(0.5,1.5$, and $\left.2.5 \mathrm{mmol} \cdot \mathrm{L}^{-1}\right)$, cisplatin $\left(0.025 \mathrm{mmol} \cdot \mathrm{L}^{-1}\right)$, or DMSO were collected and extracted with $1 \times$ cell lysis buffer (Promega, Madison, WI, USA). Proteins $(50 \mu \mathrm{g})$ from each sample were subjected to $4 \%-20 \%$ precast polyacrylamide gel (Bio-Rad, Hercules, CA, USA) electrophoresis and transferred to nitrocellulose membranes (Bio-Rad, USA). For PCNA, N-myc, XIAP, and survivin (Santa Cruz Biotechnology, Santa Cruz, CA, USA) detections, the primary antibody dilutions were 1: $1000,1: 500,1: 500$, and 1:500, respectively, followed by 1 : 3000 dilution of goat antirabbit horseradish peroxidase-labeled antibody (Bio-Rad, USA). The ECL substrate kit (Amersham, Piscataway, NJ, USA) was used for the chemiluminescent detection of signals with autoradiography film (Amersham, USA).

Statistical analysis Unless otherwise stated, all data were shown as mean \pm SEM. Statistical significance $(P<0.05)$ was determined by $t$-test or ANOVA followed by an assessment of differences using SPSS 12.0 software (SPSS, Chicago, IL, USA).

\section{Results}

Natural jasmonates of different structures suppress the growth of SH-SY 5 Y cells To explore the effects of natural jasmonates (Figure 1) on human neuroblastoma cells, we first observed the cell proliferation changes in cultured SH-SY5Y cells. As shown in Figure 2A, the MTT colorimetric assay indicated that methyl jasmonate $\left(0.5,1.5\right.$, and $\left.2.5 \mathrm{mmol} \cdot \mathrm{L}^{-1}\right)$, cis-jasmone $\left(0.5,1.5\right.$, and $\left.2.5 \mathrm{mmol} \cdot \mathrm{L}^{-1}\right)$, jasmonic acid $(0.5,1.5$, and $\left.2.5 \mathrm{mmol} \cdot \mathrm{L}^{-1}\right)$, and cisplatin $\left(0.025,0.05\right.$, and $\left.0.1 \mathrm{mmol} \cdot \mathrm{L}^{-1}\right)$, but not DMSO, inhibited the cell proliferation of SH-SY5Y cells in a dose- and time-dependent manner. The incubation of SH-SY5Y cells with $2.5 \mathrm{mmol} \cdot \mathrm{L}^{-1}$ methyl jasmonate, cisjasmone, and jasmonic acid, and $0.1 \mathrm{mmol} \cdot \mathrm{L}^{-1}$ cisplatin, resulted in a decrease of cell proliferation by $81.7 \%, 48.9 \%, 12.65 \%$,
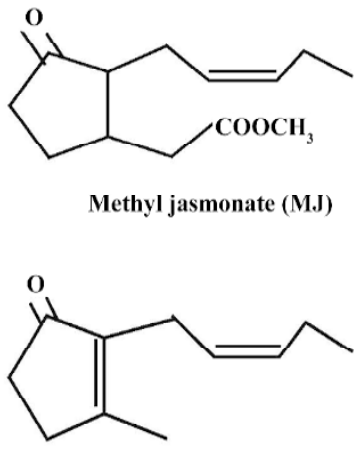

cis-jasmone (CJ)

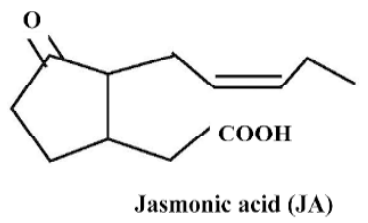

Figure 1. Natural jasmonates structures. Three of the most common natural jasmonates, methyl jasmonate, cis-jasmone, and jasmonic acid, were involved in this study, and differences in their chemical structures were compared.

and $86.4 \%$, respectively. The $\mathrm{IC}_{50}$ values of the $\mathrm{SH}-\mathrm{SY} 5 \mathrm{Y}$ cells treated with methyl jasmonate, cis-jasmone, and jasmonic acid for $24 \mathrm{~h}$ were $1.65,3.33$, and $556.8 \mathrm{mmol} \cdot \mathrm{L}^{-1}$, respectively, which were higher than that of cisplatin $(0.025$ $\left.\mathrm{mmol} \cdot \mathrm{L}^{-1}\right)$ as a positive control. Moreover, cisplatin $(0.025$, 0.05 , and $0.1 \mathrm{mmol} \cdot \mathrm{L}^{-1}$ ), but not methyl jasmonate, cisjasmone, jasmonic acid, or DMSO, suppressed the cell proliferation of the HEK 293 cell line by 46.8\%-72.6\% (Figure 2B). The colony formation assay further demonstrated that the administration of natural jasmonates and cisplatin, but not DMSO, resulted in the decreased cell proliferation of SH-SY5Y cells (Figure 3 ). The administration of $2.5 \mathrm{mmol} \cdot \mathrm{L}^{-1}$ methyl jasmonate, cis-jasmone, and jasmonic acid resulted in the loss of colony formation capability of SH-SY5Y cells by $87.6 \%, 64.1 \%$, and $21.2 \%$, respectively.

Natural jasmonates induce cell cycle arrest and apoptosis in SH-SY5Y cells As previous studies have demonstrated that inducing apoptosis is one of the mechanisms of the anticancer effects of jasmonates ${ }^{[5,6,12]}$, we hypothesized that natural jasmonates may also induce apoptosis in cultured neuroblastoma SH-SY5Y cells. The cell cycle assay showed that methyl jasmonate and cis-jasmone, but not jasmonic acid, induced $\mathrm{G}_{2} / \mathrm{M}$ phase arrest in cultured SH-SY5Y cells (Table 1). As shown in Figure 4A, Hoechst 33258 staining indicated that the administration of methyl jasmonate $(2.5$ $\left.\mathrm{mmol} \cdot \mathrm{L}^{-1}\right)$, cis-jasmone $\left(2.5 \mathrm{mmol} \cdot \mathrm{L}^{-1}\right)$, jasmonic acid $(2.5$ $\left.\mathrm{mmol} \cdot \mathrm{L}^{-1}\right)$, and cisplatin $\left(0.025 \mathrm{mmol} \cdot \mathrm{L}^{-1}\right)$, rather than DMSO, 
A
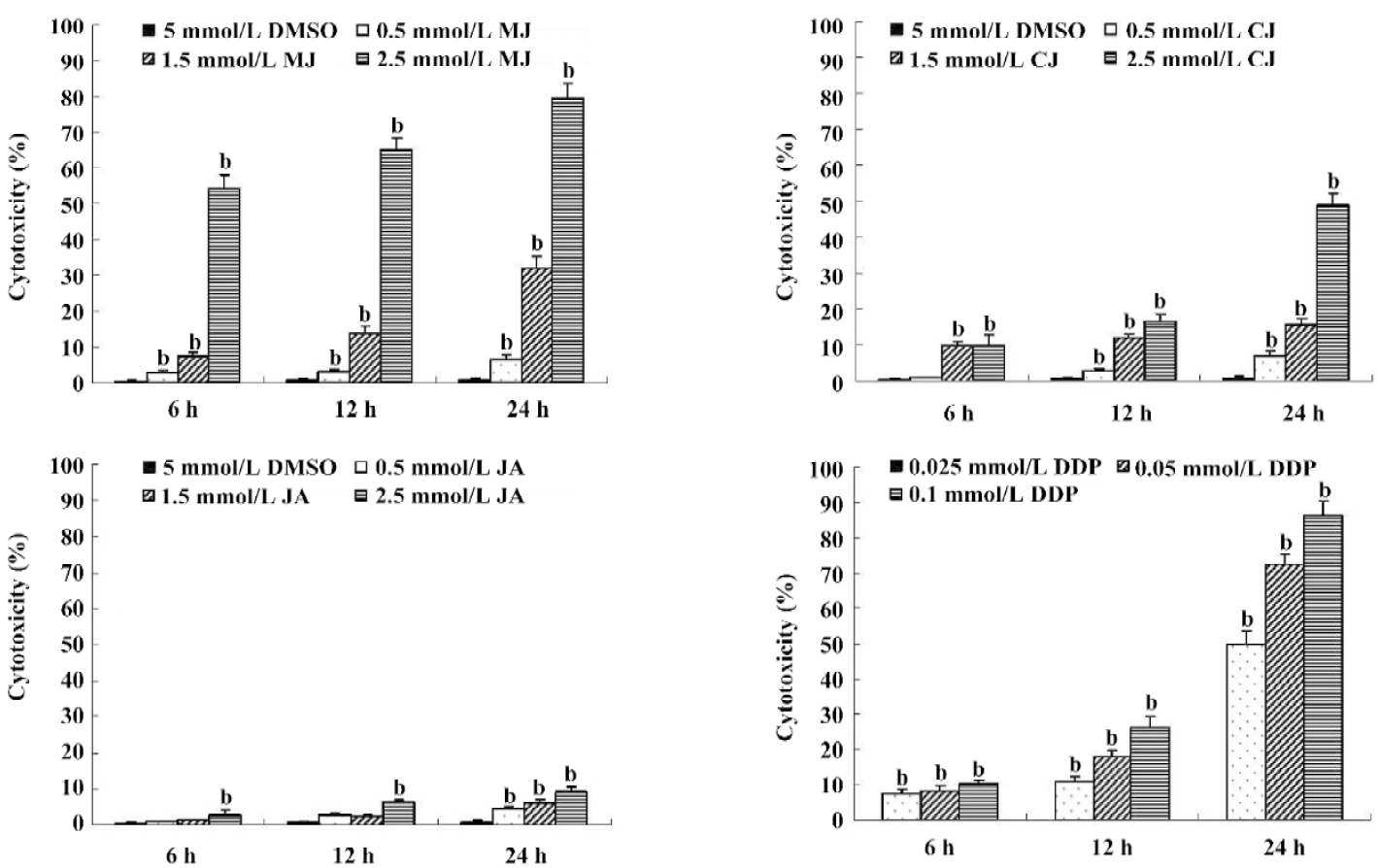

B
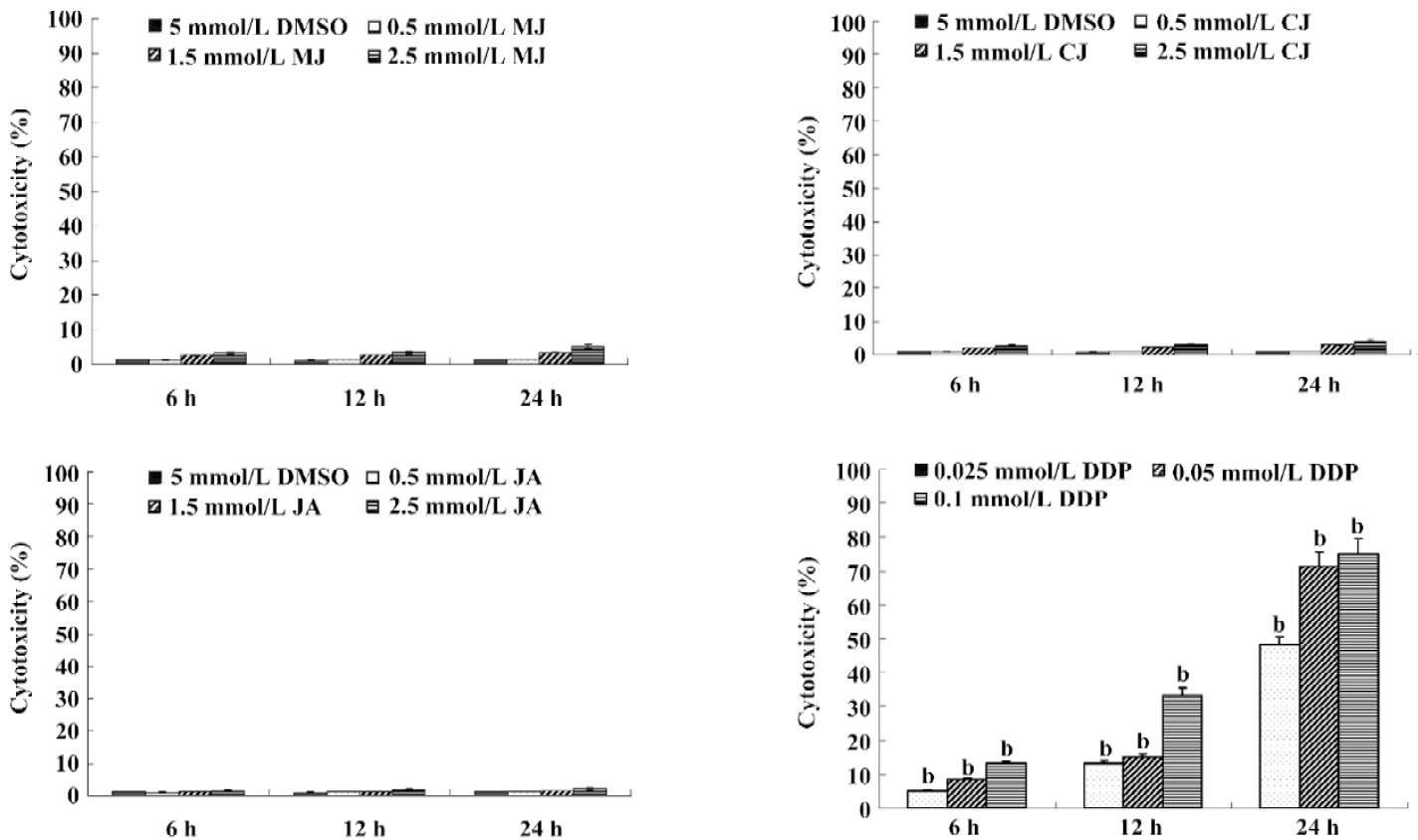

Figure 2. Natural jasmonates suppress the proliferation of SH-SY5Y cells and HEK 293 cells. Confluent monolayers of human neuroblastoma SH-SY5Y cells and HEK 293 cells were seeded into each well of 96-well plates and incubated with various concentration of DMSO (5 mmol/L), methyl jasmonate (MJ, 0.5-2.5 mmol/L), cis-jasmone (CJ, 0.5-2.5 mmol/L), jasmonic acid (JA, 0.5-2.5 mmol/L), or cisplatin (DDP, 0.025-0.1 $\mathrm{mmol} / \mathrm{L}$ ) as indicated. MTT colorimetric assay indicated that methyl jasmonate, cis-jasmone, jasmonic acid, and cisplatin, but not DMSO, inhibited the cell proliferation of SH-SY5Y cells in a dose- and time-dependent manner(A). Moreover, the cell proliferation of HEK 293 was suppressed by cisplatin, but not by methyl jasmonate, cis-jasmone, or jasmonic acid (B). There was significant increase from control treated with DMSO $\left({ }^{\mathrm{b}} P<0.05\right)$. Triplicate experiments were performed with essentially identical results. 
$\Lambda$

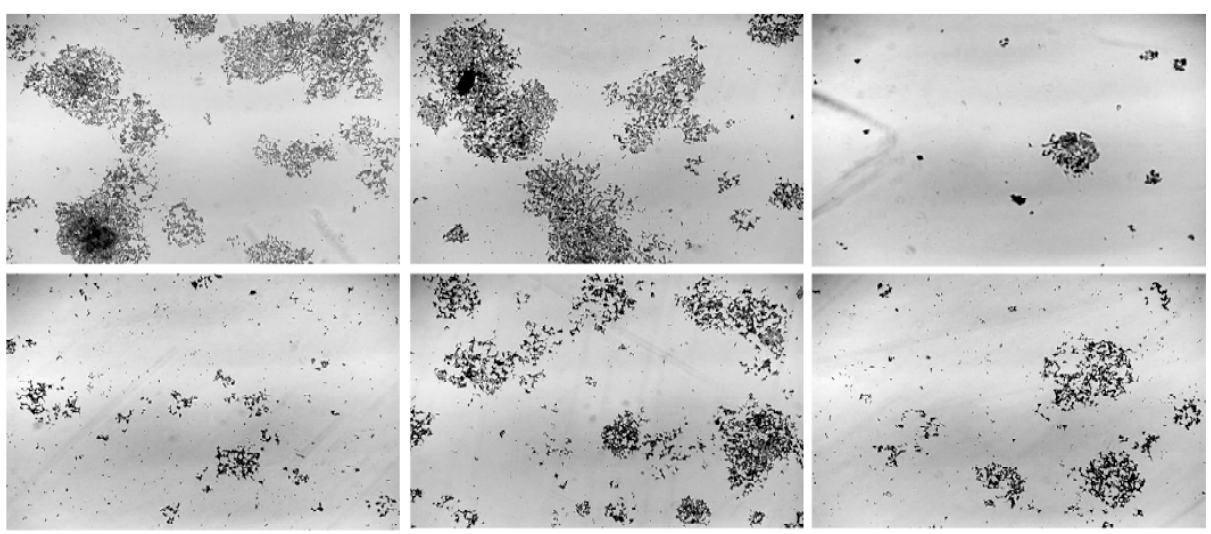

B

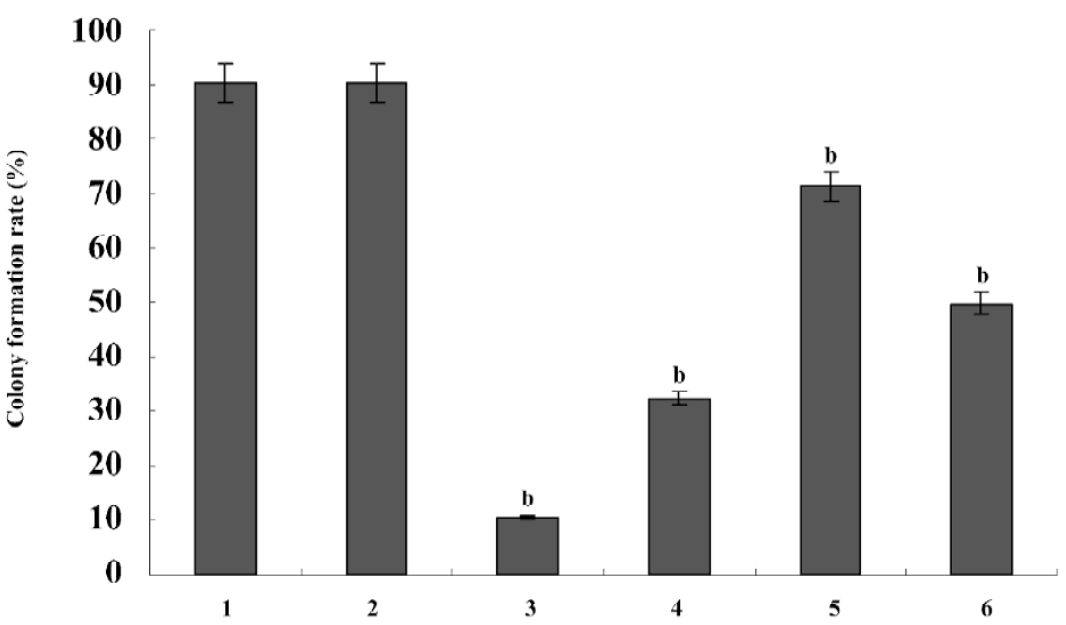

Figure 3. Natural jasmonates suppress the colony formation of SH-SY5Y cells. Confluent monolayers of SH-SY5Y cells were seeded at a density of 500/mL on $35 \mathrm{~mm}$ dishes. After an overnight incubation to allow cell attachment, cells were incubated with natural jasmonates, cisplatin, or DMSO as indicated. Colonies were allowed to grow for 10-14 d. (A) administration of methyl jasmonate, cis-jasmone, jasmonic acid, and cisplatin resulted in decreased colony formation capabilities of SH-SY5Y cells. 1: negative control; 2: $5 \mathrm{mmol} / \mathrm{L}$ DMSO control; 3: $2.5 \mathrm{mmol} / \mathrm{L}$ methyl jasmonate; 4: $2.5 \mathrm{mmol} / \mathrm{L}$ cis-jasmone; $5: 2.5 \mathrm{mmol} / \mathrm{L}$ Jasmonic acid; 6: $0.025 \mathrm{mmol} / \mathrm{L}$ cisplatin. (B) sensitivity of SHSY5Y cells was found to be in the following order: methyl jasmonate $>$ cis-jasmone $>$ jasmonic acid. There was significant decrease from untreated control $\left({ }^{b} P<0.05\right)$. Triplicate experiments were performed with essentially identical results.

to SH-SY5Y cells resulted in eccentric nuclei and nuclei condensation, characteristic changes of apoptosis. The Annexin V-FITC/PI staining flow cytometry was used to quantify the number of apoptotic cells induced by jasmonates. As shown in Figure 4B, natural jasmonates (2.5 $\mathrm{mmol} \cdot \mathrm{L}^{-1}$ ) exerted strong apoptosis-inducing effects on neuroblastoma cells. The cellular apoptotic rates of methyl jasmonate-, cis-jasmone-, and jasmonic acid-treated SH-SY5Y cells were $78.9 \%, 37.46 \%$, and $8.32 \%$, respectively (Table 2), which were higher than that of untreated cells (4.29\%).

Methyl jasmonate downregulates PCNA and $\mathrm{N}$-myc in SH-SY5Y cells As indicated earlier, natural jasmonates suppress the cell proliferation of neuroblastoma cells, so we hypothesized that jasmonates may modulate the expression of PCNA and N-myc, critical proteins that are involved in neuroblastoma development and progression ${ }^{[13,14]}$. To meet this end, the SH-SY5Y cells were treated with $0.5,1.5$, and $2.5 \mathrm{mmol} \cdot \mathrm{L}^{-1}$ methyl jasmonate and $0.025 \mathrm{mmol} \cdot \mathrm{L}^{-1}$ cisplatin for $24 \mathrm{~h}$. As shown in Figure 5, Western blotting demonstrated that methyl jasmonate, but not DMSO or cisplatin, decreased the expression of PCNA and N-myc in the SHSY5Y cells in a dose-dependent manner. The administration of $0.5,1.5$, and $2.5 \mathrm{mmol} \cdot \mathrm{L}^{-1}$ methyl jasmonate resulted in the downregulation of PCNA and N-myc in the SH-SY5Y cells by $31.9 \%-64.5 \%$ and $17.1 \%-68.4 \%$, respectively.

Methyl jasmonate downregulates XIAP and survivin in 
Table 1. Cell cycle phases of SH-SY5Y cells treated by various drugs for $24 \mathrm{~h} . n=3$. Mean \pm SD. ${ }^{b} P<0.05,{ }^{\mathrm{c}} P<0.01 v s$ control group.

\begin{tabular}{cccc}
\hline Group & $\mathrm{G}_{0} / \mathrm{G}_{1}(\%)$ & $\mathrm{S}(\%)$ & $\mathrm{G}_{2} / \mathrm{M}(\%)$ \\
\hline Negative control & $72.38 \pm 0.57$ & $23.26 \pm 0.63$ & $4.36 \pm 0.40$ \\
$5 \mathrm{mmol} / \mathrm{L}$ DMSO & $73.08 \pm 1.53$ & $23.10 \pm 0.43$ & $3.82 \pm 1.19$ \\
$0.5 \mathrm{mmol} / \mathrm{L} \mathrm{MJ}$ & $70.76 \pm 0.74^{\mathrm{b}}$ & $24.15 \pm 1.72$ & $5.09 \pm 1.49$ \\
$1.5 \mathrm{mmol} / \mathrm{L} \mathrm{MJ}$ & $65.20 \pm 0.95^{\mathrm{c}}$ & $18.73 \pm 0.97^{\mathrm{c}}$ & $16.07 \pm 1.79^{\mathrm{c}}$ \\
$2.5 \mathrm{mmol} / \mathrm{L} \mathrm{MJ}$ & $59.65 \pm 2.08^{\mathrm{c}}$ & $19.38 \pm 1.42^{\mathrm{b}}$ & $20.97 \pm 0.73^{\mathrm{c}}$ \\
$0.5 \mathrm{mmol} / \mathrm{L} \mathrm{CJ}$ & $72.85 \pm 1.70$ & $22.90 \pm 1.60$ & $4.25 \pm 2.19$ \\
$1.5 \mathrm{mmol} / \mathrm{L} \mathrm{CJ}$ & $68.24 \pm 1.01^{\mathrm{c}}$ & $20.55 \pm 0.71^{\mathrm{c}}$ & $11.21 \pm 0.31^{\mathrm{c}}$ \\
$2.5 \mathrm{mmol} / \mathrm{L} \mathrm{CJ}$ & $58.75 \pm 1.65^{\mathrm{c}}$ & $21.01 \pm 0.17^{\mathrm{c}}$ & $20.24 \pm 1.49^{\mathrm{c}}$ \\
$0.5 \mathrm{mmol} / \mathrm{L} \mathrm{JA}$ & $74.34 \pm 2.21$ & $22.53 \pm 1.07$ & $3.13 \pm 2.11$ \\
$1.5 \mathrm{mmol} / \mathrm{L} \mathrm{JA}$ & $74.58 \pm 1.63$ & $20.62 \pm 2.30$ & $4.80 \pm 0.91$ \\
$2.5 \mathrm{mmol} / \mathrm{L} \mathrm{JA}$ & $73.18 \pm 2.92$ & $9.50 \pm 0.18^{\mathrm{c}}$ & $4.03 \pm 2.49$ \\
$0.025 \mathrm{mmol} / \mathrm{L} \mathrm{DDP}$ & $85.98 \pm 2.19^{\mathrm{c}}$ & & $4.52 \pm 2.06$ \\
\hline
\end{tabular}

MJ, methyl jasmonate; CJ, cis-jasmone; JA, jasmonic acid; DDP, cisplatin

Table 2. Cell phenotypes of SH-SY5Y cells treated by various drugs for 24 h. $n=3$. Mean \pm SD. ${ }^{b} P<0.05,{ }^{c} P<0.01 v s$ control group.

\begin{tabular}{lcrrr}
\hline \multicolumn{1}{c}{ Group } & Annexin $\mathrm{V}^{-} / \mathrm{PI}^{-}(\%)$ & Annexin $\mathrm{V}^{+} / \mathrm{PI}^{-}(\%)$ & Annexin $\mathrm{V}^{+} / \mathrm{PI}^{+}(\%)$ & Annexin V/PI+(\%) \\
\hline & & & & \\
Negative control & $94.87 \pm 3.06$ & $1.17 \pm 0.07$ & $3.12 \pm 0.31$ & $0.84 \pm 0.05$ \\
$2.5 \mathrm{mmol} / \mathrm{L} \mathrm{MJ}$ & $13.54 \pm 1.35^{\mathrm{c}}$ & $11.38 \pm 1.12^{\mathrm{c}}$ & $67.52 \pm 2.01^{\mathrm{c}}$ & $7.56 \pm 1.47^{\mathrm{c}}$ \\
$2.5 \mathrm{mmol} / \mathrm{L} \mathrm{CJ}$ & $49.12 \pm 2.12^{\mathrm{c}}$ & $9.45 \pm 0.83^{\mathrm{c}}$ & $28.01 \pm 1.36^{\mathrm{c}}$ & $13.42 \pm 0.41^{\mathrm{c}}$ \\
$2.5 \mathrm{mmol} / \mathrm{L} \mathrm{JA}$ & $89.94 \pm 3.01^{\mathrm{b}}$ & $3.28 \pm 0.29^{\mathrm{b}}$ & $5.04 \pm 1.42^{\mathrm{b}}$ & $1.74 \pm 0.09$ \\
$0.025 \mathrm{mmol} / \mathrm{L} \mathrm{DDP}$ & $48.37 \pm 2.04^{\mathrm{c}}$ & $5.22 \pm 1.18^{\mathrm{c}}$ & $19.88 \pm 0.96^{\mathrm{c}}$ & $26.53 \pm 1.73^{\mathrm{c}}$ \\
\hline
\end{tabular}

SH-SY5Y cells As several published studies have demonstrated that the IAP family plays a role in oncogenesis via its effective suppression of apoptosis ${ }^{[15]}$, we hypothesized that IAP might be the targets of jasmonates in human neuroblastoma SH-SY5Y cells. To meet this end, we performed Western blotting to measure the expression of XIAP and survivin, important members of the IAP family. As shown in Figure 6, methyl jasmonate $\left(0.5,1.5\right.$, and $\left.2.5 \mathrm{mmol} \cdot \mathrm{L}^{-1}\right)$, but not DMSO or cisplatin, attenuated the expression of XIAP and survivin in a dose-dependent manner in SH-SY5Y cells. The administration of $0.5,1.5$, and $2.5 \mathrm{mmol} \cdot \mathrm{L}^{-1}$ methyl jasmonate resulted in the downregulation of XIAP and survivin in SH-SY5Y cells by $17.6 \%-71.4 \%$ and $21.5 \%-61.5 \%$, respectively.

\section{Discussion}

Jasmonates are potent lipid regulators that mediate responses to mechanical and infectious stresses throughout the plant kingdom ${ }^{[16,17]}$. Previous evidence has indicated that salicylic acid, another plant hormone, suppresses the proliferation of various types of cancer cells, including lymphoblastic leukemia, prostate, breast, and melanoma can- cer cells ${ }^{[18]}$, suggesting that plant stress hormones are a promising group of plant-derived anticancer agents. A major characteristic expected of a potential anticancer agent is its ability to selectively affect cancer cells while sparing normal ones. In the current study, we demonstrated that natural jasmonates exert anticancer activity on human neuroblastoma SH-SY5Y cells. Moreover, the growth of the cultured HEK 293 cell line was not affected by jasmonates, which was consistent with previous evidence that normal cells are resistant to jasmonate-mediated cytotoxicity ${ }^{[10]}$. These findings suggest that the identification of plant-derived molecules with known roles in plants may provide novel candidates for use in clinical oncology.

The naturally-occurring jasmonates, methyl jasmonate, cis-jasmone, and jasmonic acid, have been compared in vitro using leukemia, lymphoma, breast, prostate, and melanoma cancer cells as targets ${ }^{[5]}$. Their anticancer activities can also be generally summed up as methyl jasmonate $>$ cis-jasmone $>$ jasmonic acid ${ }^{[19]}$. Thus the methyl group appears to contribute considerably to the cytotoxic effects of MJ. In the current study, we demonstrated that natural jasmonates of dif- 
A
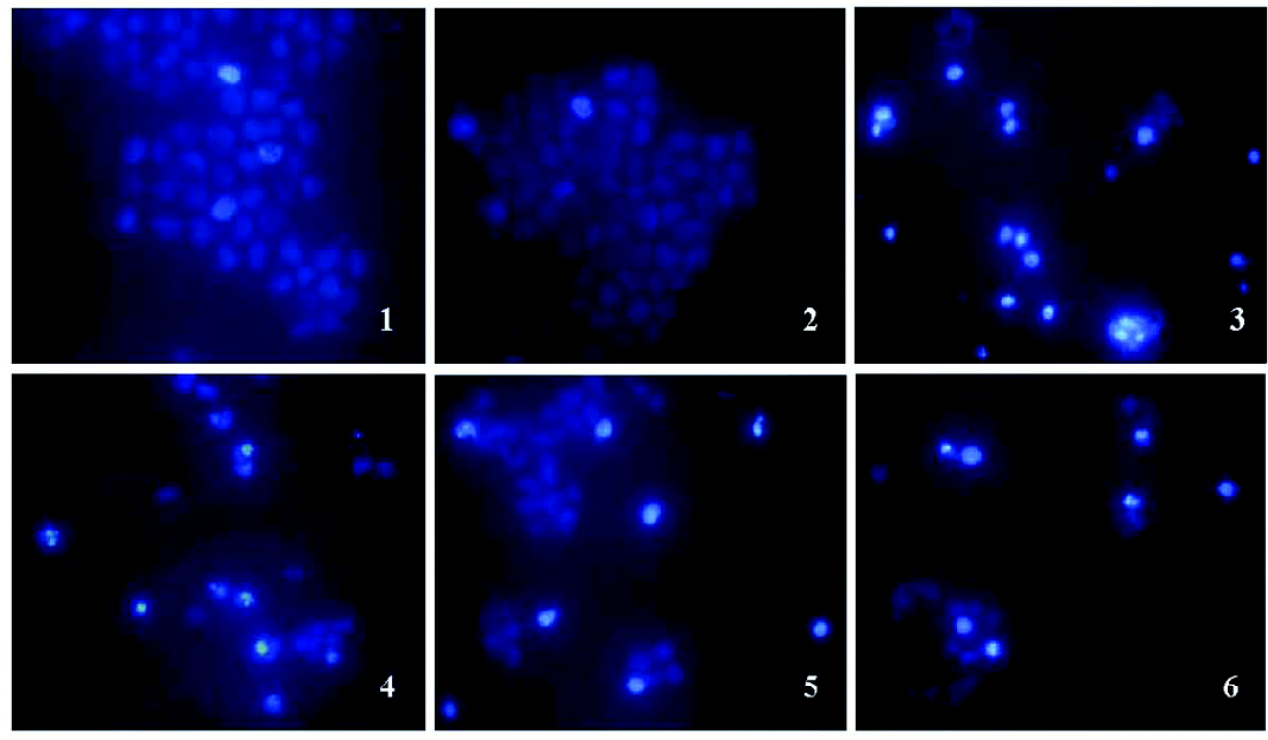
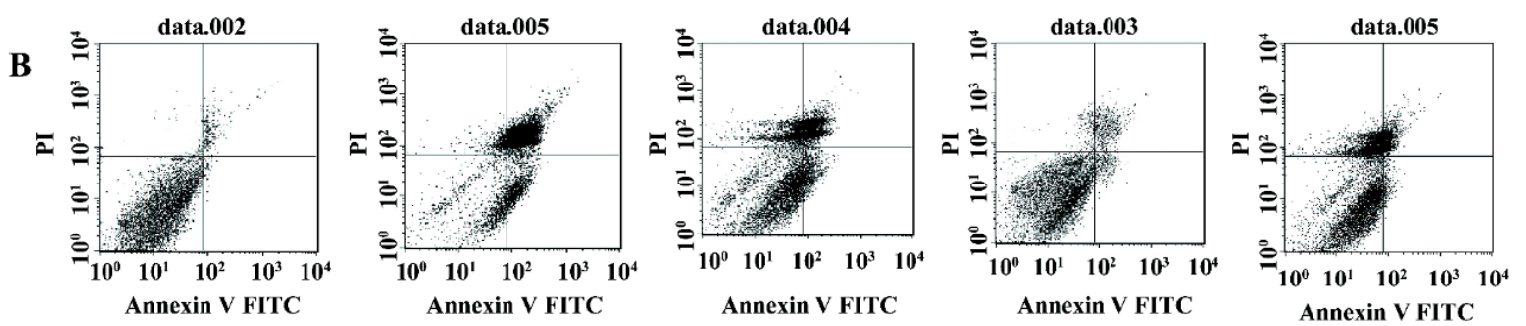

Figure 4. Natural jasmonates induce apoptosis in SH-SY5Y cells. Confluent monolayers of SH-SY5Y cells were incubated with DMSO, methyl jasmonate, cis-jasmone, jasmonic acid, or cisplatin for $24 \mathrm{~h}$ as indicated. Cells were collected for Hoechst 33258 staining and Annexin V-FITC/ PI staining flow cytometry. (A) Hoechst 33258 staining indicated that the administration of methyl jasmonate, cis-jasmone, jasmonic acid, and cisplatin, rather than DMSO, to SH-SY5Y cells, resulted in eccentric nuclei and nuclei condensation, characteristic changes of apoptosis. 200×magnification. 1: Negative control; 2: $5 \mathrm{mmol} / \mathrm{L}$ DMSO control; $3: 2.5 \mathrm{mmol} / \mathrm{L}$ methyl jasmonate; $4: 2.5 \mathrm{mmol} / \mathrm{L}$ cis-jasmone; 5: 2.5 mmol/L Jasmonic acid; 6. $0.025 \mathrm{mmol} / \mathrm{L}$ cisplatin. (B) flow cytometry results indicated that natural jasmonates, methyl jasmonate, cisjasmone, and jasmonic acid, induced apoptosis in cultured SH-SY5Y cells. Sensitivity of SH-SY5Y cells was found to be in the following order: methyl jasmonate>cis-jasmone $>$ jasmonic acid. Triplicate experiments were performed with essentially identical results. 1: Negative control; 2: $2.5 \mathrm{mmol} / \mathrm{L}$ methyl jasmonate; 3: $2.5 \mathrm{mmol} / \mathrm{L}$ cis-jasmone; 4: $2.5 \mathrm{mmol} / \mathrm{L}$ jasmonic acid; $5: 0.025 \mathrm{mmol} / \mathrm{L} \mathrm{cisplatin}$.

ferent structures suppress the growth of human neuroblastoma SH-SY5Y cells in a dose- and time-dependent manner, and their efficiency is consistent with previous reports ${ }^{[19]}$. Since the structures of jasmonates are different from any group of currently available anticancer agents, these findings suggest that potential future research directions should include a structure-function analysis in order to identify the actual jasmonate target molecule(s) and the discovery of new derivatives with a superior therapeutic index.

PCNA is a $36 \mathrm{kDa}$ nuclear protein, and its level correlates directly with the rate of cellular proliferation ${ }^{[20,21]}$. Oue et al reported that PCNA immunostaining is an appropriate index of proliferation activity in neuroblastomas. It relates well with tumor growth and other prognostic factors, and a high
PCNA expression is significantly related with a poor survival rate $e^{[13]}$. Combined with the results from the colony formation assay that jasmonates inhibit the cell proliferation of SH-SY5Y cells, we hypothesized that jasmonates might influence the PCNA expression of human neuroblastoma cells. We found that methyl jasmonate downregulates the PCNA expression of cultured SH-SY5Y cells in a dose-dependent manner. We believe that PCNA is one of the target molecules of jasmonates, and the downregulation of PCNA is associated with the methyl jasmonate-induced cell proliferation inhibition of SH-SY5Y cells.

$\mathrm{N}$-myc is a member of the myc family of proto-oncogenes, in which $\mathrm{C}$-myc, $\mathrm{N}$-myc, and L-myc have strong oncogenic potential $^{[22]}$. Approximately $25 \%-30 \%$ of primary untreated 

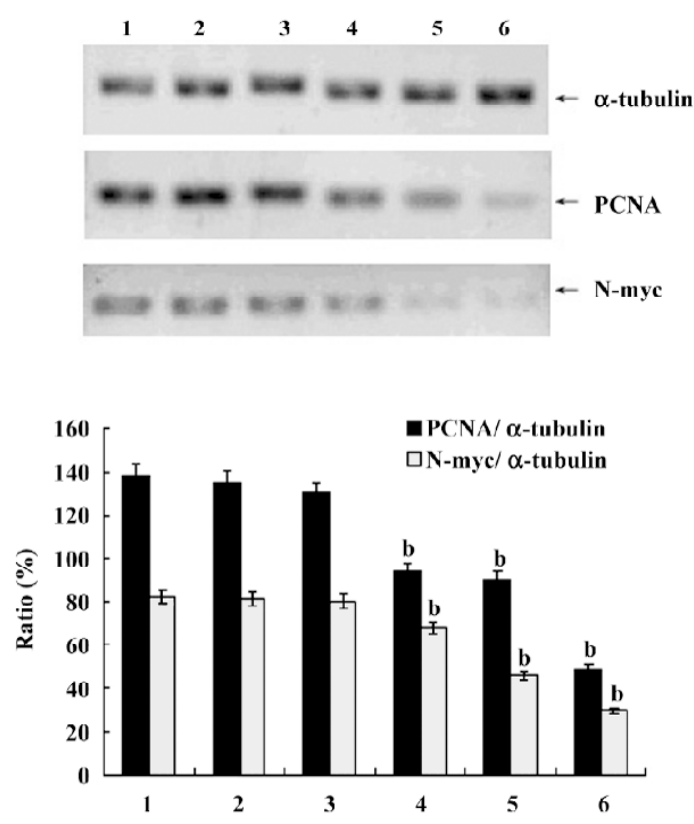

Figure 5. Methyl jasmonate downregulates the expressions of PCNA and N-myc in SH-SY5Y cells. Confluent monolayers of SH-SY5Y cells were treated with DMSO, methyl jasmonates, or cisplatin for 24 $\mathrm{h}$ as indicated. Western blotting demonstrated that methyl jasmonate, but not DMSO or cisplatin, decreased the expressions of PCNA and $\mathrm{N}$-myc in SH-SY5Y cells in a dose-dependent manner. There was significant decrease from untreated control $\left({ }^{\mathrm{b}} P<0.05\right)$. Triplicate experiments were performed with essentially identical results. 1: Negative control; 2: $5 \mathrm{mmol} / \mathrm{L}$ DMSO control; $3: 0.025 \mathrm{mmol} / \mathrm{L}$ cisplatin; 4: $0.5 \mathrm{mmol} / \mathrm{L}$ methyl jasmonate; $5: 1.5 \mathrm{mmol} / \mathrm{L}$ methyl jasmonate; 6: $2.5 \mathrm{mmol} / \mathrm{L}$ methyl jasmonate.

neuroblastomas present amplification/overexpression of the $\mathrm{N}$-myc proto-oncogene, which is associated with advanced stage disease, rapid progression, and poor prognosis ${ }^{[23]}$. The downregulation of N-myc expression, either by antisense treatment targeted against N-myc mRNA or by retinoids, has been shown to decrease proliferation and/or induce neuronal differentiation of neuroblastoma cells ${ }^{[24,25]}$. In the current study, we found that methyl jasmonate suppresses the $\mathrm{N}$-myc expression in SH-SY5Y cells, which might be correlated with the jasmonate-mediated anticancer activity on human neuroblastoma SH-SY5Y cells.

To date, 8 human IAP have been identified, including XIAP and survivin ${ }^{[26,27]}$. Previous evidence has indicated that in neuroblastoma cells, XIAP protects against death induced by staurosporine, thapsigargin, or serum withdrawal $^{[28]}$. In primary neuroblastomas, the survivin expression was associated with tumors of high risk and unfavorable prognosis ${ }^{[29]}$. In the current study, we found that natural jasmonates, methyl jasmonate, cis-jasmone, and jasmonic acid induced apoptosis of neuroblastoma SH-SY5Y cells. The
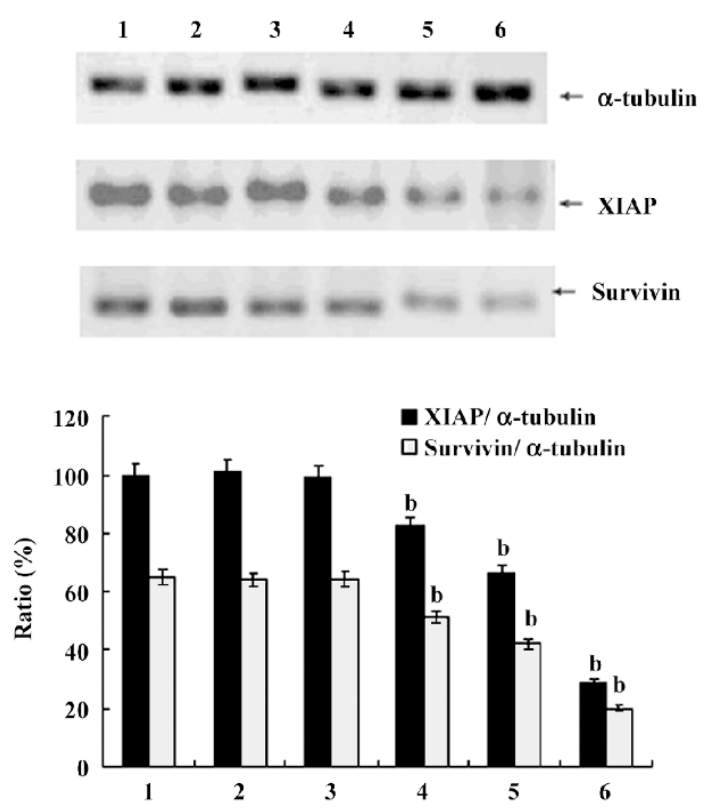

Figure 6. Methyl jasmonate downregulates the expression of XIAP and survivin in SH-SY5Y cells. Confluent monolayers of SH-SY5Y cells were stimulated with DMSO, methyl jasmonates, or cisplatin for $24 \mathrm{~h}$ as indicated. Western blotting demonstrated that methyl jasmonate decreased the XIAP and survivin expressions in SH-SY5Y cells in a dose-dependent manner. However, the administration of DMSO or cisplatin resulted in no changes in the XIAP and survivin levels. b, significant decrease from untreated control $(P<0.05)$. Triplicate experiments were performed with essentially identical results. 1: Negative control; 2: $5 \mathrm{mmol} / \mathrm{L}$ DMSO control; 3: $0.025 \mathrm{mmol} / \mathrm{L}$ cisplatine; $4: 0.5 \mathrm{mmol} / \mathrm{L}$ methyl jasmonate; $5: 1.5 \mathrm{mmol} / \mathrm{L}$ methyl jasmonate; $6: 2.5 \mathrm{mmol} / \mathrm{L}$ methyl jasmonate.

expressions of XIAP and survivin were suppressed in methyl jasmonate-treated SH-SY5Y cells. We believe that jasmonates may modulate IAP to exert anticancer activity, which warrants further study.

In summary, we demonstrated that 3 kinds of natural jasmonates, methyl jasmonate, cis-jasmone, and jasmonic acid suppress cell proliferation and induce apoptosis in the human neuroblastoma cell line SH-SY5Y. The anticancer activities of jasmonates, are different along with their various chemical structures, which can be summed up as methyl jasmonate $>$ cis-jasmone $>$ jasmonic acid. In addition, methyl jasmonate attenuates the expression of PCNA and N-myc, and downregulates the expression of XIAP and survivin, which might be one of the mechanisms of jasmonate-mediated anticancer activity on human neuroblastoma SH-SY5Y cells.

\section{Acknowledgements}

We are grateful to Mr John LANGER (Johns Hopkins University School of Medicine, Baltimore, MD, USA) for his 
help in the preparation of this manuscript.

\section{Author contribution}

Qiang-song TONG, Fu-qing ZENG designed research; Guo-song JIANG, Li-duan ZHENG performed research; Shaotao TANG, Ji-hua DONG contributed analytical reagents and tools; Guo-song JIANG, Jia-bin CAI, Yuan LIU analyzed data; Guo-song JIANG, Qiang-song TONG wrote the paper.

\section{References}

1 Schor NF. Neuroblastoma as a neurobiological disease. J Neurooncol 1999; 41: 159-66.

2 Westermann F, Schwab M. Genetic parameters of neuroblastomas. Cancer Lett 2002; 184: 127-47.

3 Nakagawara A, Rima-Nakagawara M, Scavarda NJ, Azar CG, Cantor AB, Brodeur GM. Association between high levels of expression of the TRK gene and favorable outcome in human neuroblastoma. New Engl J Med 1993; 328: 847-54.

4 Flescher E. Jasmonates in cancer therapy. Cancer Lett 2007; 245: $1-10$

5 Fingrut O, Flescher E. Plant stress hormones suppress the proliferation and induce apoptosis in human cancer cells. Leukemia 2002; 16: 608-16.

6 Kim JH, Lee SY, Oh SY, Han SI, Park HG, Yoo MA, et al. Methyl jasmonate induces apoptosis through induction of Bax/ Bcl-XS and activation of caspase-3 via ROS production in A549 cells. Oncol Rep 2004; 12: 1233-8.

7 Mosmann T. Rapid colorimetric assay for cellular growth and survival: application to proliferation and cytotoxicity assays. J Immunol Methods 1983; 65: 55-63.

8 Lebrin F, Goumans MJ, Jonker L, Carvalho RL, Valdimarsdottir $\mathrm{G}$, Thorikay M, et al. Endoglin promotes endothelial cell proliferation and TGF-beta/ALK1 signal transduction. EMBO J 2004; 23: 4018-28.

9 Overbeeke R, Steffens-Nakken H, Vermes I, Reutelingsperger C, Haanen C. Early features of apoptosis detected by four different flow cytometry assays. Apoptosis 1998; 3: 115-21.

10 Movsesyan VA, Yakovlev AG, Dabaghyan EA, Stoica BA, Faden AI. Ceramide induces neuronal apoptosis through the caspase-9/ caspase-3 pathway. Biochem Biophys Res Commun 2002; 299: 201-7.

11 Pietra G, Mortarini R, Parmiani G, Anichini A. Phases of apoptosis of melanoma cells, but not of normal melanocytes, differently affect maturation of myeloid dendritic cells. Cancer Res 2001; 61: 8218-26.

12 Ishii Y, Kiyota H, Sakai S, Honma Y. Induction of differentiation of human myeloid leukemia cells by jasmonates, plant hormones. Leukemia 2004; 18: 1413-9.

13 Oue T, Fukuzawa M, Kamata S, Okada A. Immunohistochemical analysis of proliferating cell nuclear antigen expression in human neuroblastoma. J Pediatr Surg 1995; 30: 528-32.
14 Tonelli R, Purgato S, Camerin C, Fronza R, Bologna F, Alboresi $\mathrm{S}$, et al. Anti-gene peptide nucleic acid specifically inhibits MYCN expression in human neuroblastoma cells leading to cell growth inhibition and apoptosis. Mol Cancer Ther 2005; 4: 779-86.

15 Nachmias B, Ashhab Y, Ben-Yehuda D. The inhibitor of apoptosis protein family (IAPs): an emerging therapeutic target in cancer. Semin Cancer Biol 2004; 14: 231-43.

16 Wasternack C, Hause B. Jasmonates and octadecanoids: signals in plant stress responses and development. Prog Nucleic Acid Res Mol Biol 2002; 72: 165-221.

17 Liechti R, Farmer EE. The Jasmonate Pathway. Science 2002; 296: $1649-50$.

18 Sotiriou C, Lacroix M, Lagneaux L, Berchem G, Body JJ. The aspirin metabolite salicylate inhibits breast cancer cells growth and their synthesis of the osteolytic cytokines interleukins-6 and -11. Anticancer Res 1999; 19: 2997-3006.

19 Rotem R, Heyfets A, Fingrut O, Blickstein D, Shaklai M, Flescher E. Jasmonates: novel anticancer agents acting directly and selectively on human cancer cell mitochondria. Cancer Res 2005; 65: 1984-93.

20 Bravo R, Frank R, Blundell PA, Donald-Bravo H. Cyclin/PCNA is the auxiliary protein of DNA polymerase-[delta]. Nature 1987; 326: 515-7.

21 Prelich G, Tan CK, Kostura M, Mathews MB, So AG, Downey $\mathrm{KM}$, et al. Functional identity of proliferating cell nuclear antigen and a DNA polymerase-[delta] auxiliary protein. Nature 1987; 326: 517-20.

22 Mukherjee B, Morgenbesser SD, DePinho RA. Myc family oncoproteins function through a common pathway to transform normal cells in culture: cross-interference by Max and transacting dominant mutants. Genes Dev 1992; 6: 1480-92.

23 Brodeur GM. Neuroblastoma: biological insights into a clinical enigma. Nat Rev Cancer 2003; 3: 203-16.

24 Galderisi U, Di Bernardo G, Cipollaro M, Peluso G, Cascino A, Cotrufo R, et al. Differentiation and apoptosis of neuroblastoma cells: role of N-myc gene product. J Cell Biochem 1999; 73: 97105.

25 Matsuo T, Thiele CJ. p27Kip1: a key mediator of retinoic acid induced growth arrest in the SMS-KCNR human neuroblastoma cell line. Oncogene 1998; 16: 3337-43.

26 Hunter AM, LaCasse EC, Korneluk RG. The inhibitors of apoptosis (IAPs) as cancer targets. Apoptosis 2007; 12: 154368 .

27 Fulda S. Inhibitor of apoptosis proteins as targets for anticancer therapy. Expert Rev Anticancer Ther 2007; 7: 1255-64.

28 Yu LY, Korhonen L, Martinez R, Jokitalo E, Chen Y, Arumäe U, et al. Regulation of sympathetic neuron and neuroblastoma cell death by XIAP and its association with proteasomes in neural cells. Mol Cell Neurosci 2003; 22: 308-18.

29 Azuhata T, Scott D, Takamizawa S, Wen J, Davidoff A, Fukuzawa $\mathrm{M}$, et al. The inhibitor of apoptosis protein survivin is associated with high-risk behavior of neuroblastoma. J Pediatr Surg 2001; 36: 1785-91. 